\title{
Preliminary Results of
}

\section{Hydrologic Studies at}

\section{Two Recharge Basins on}

\section{Long Island, New York}

By G. E. SEABURN

HYDROLOGY AND SOME EFFECTS OF URBANIZATION ON LONG ISLAND, NEW YORK

GEOLOGICAL SURVEY PROFESSIONAL PAPER 627-C

Prepared in cooperation with the New York

State Department of Conservation, Division

of Water Resources; the Nassau County

Department of Public Works; the Suffolk

County Board of Supervisors; and the

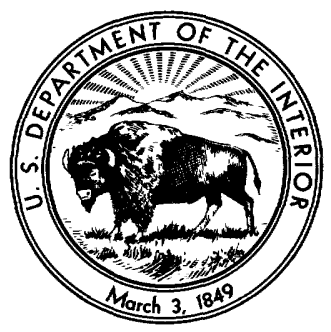

Suffolk County Water Authority 


\section{UNITED STATES DEPARTMENT OF THE INTERIOR}

WALTER J. HIGKEL, Secretary

GEOLOGICAL SURVEY

William T. Pecora, Director

For sale by the Superintendent of Documents, U.S. Government Printing Office Washington, D.C. 20402 - Price 35 cents (paper cover) 


\section{CONTENTS}

Glossary of symbols and terms

Abstract

Introduction

Purpose and scope of the water-budget study

Purpose and scope of this report.......

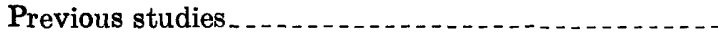

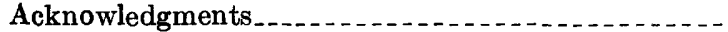

Use and general description of recharge basins on Long

Island.

Location and description of test basins

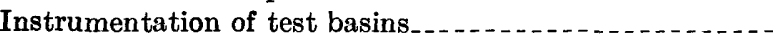

Description of apparatus

\begin{tabular}{r|r} 
Page & IV \\
C1 \\
1 \\
1 \\
2 \\
2 \\
2 \\
2 \\
\\
3 \\
4 \\
7 \\
7
\end{tabular}

Pag

Instrumentation of test basins-Continued Measurement of basin storage............. C?

Results of the study

Time response of the system.

Rainfall-runoff relations

Infiltration rates at the Westbury basin . . . . . . 12

Ground-water recharge

Summary and conclusions........... 13

References cited................ 14

Appendix

Procedures used to calibrate the weirs at the Westbury and Syosset recharge basins

\section{L L U S T R A T I O N}

Figure 1. Map showing location and general geographic features of Long Island

2. Photograph of typical recharge basin in Nassau County

3. Map showing location of Westbury and Syosset recharge basins and selected rain gages in

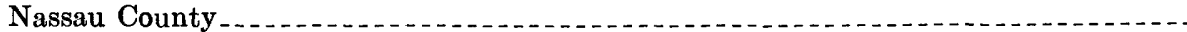

4. Aerial photograph of the Westbury recharge basin and its drainage area

5. Aerial photograph of the Syosset recharge basin and its drainage area

6. Diagrammatic section showing the drainage system and location of measuring instruments at the Westbury recharge basin.

Page

C1

3

4

5

6

7

7. Sketch of inflow-measuring apparatus located in manhole nearest each recharge basin ..... 8-13. Graphs showing:

8. Relations between water depth, water-surface area, and volume of storage for the Westbury recharge basin

9. Rainfall, inflow, basin storage, and water-table elevation for a storm on October 18, 1967, at the Westbury recharge basin

10. Relation between rainfall and inflow to the Westbury recharge basin, 1966-67

11. Relation between rainfall and inflow to the Syosset recharge basin, 1966-67... . . ...

12. Average infiltration rates calculated for 5 -minute intervals at the Westbury recharge basin for the storm on October 18, 1967

13. Relation between depth of water and average infiltration rate calculated for 5 -minute intervals in the Westbury recharge basin, during the storm of October 18, 1967 ....

14. Rating curve for $V$-notch weir at the Westbury recharge basin

15. Rating curve for $V$-notch weir at the Syosset recharge basin

(1)

\section{T A B L E S}

TABLE 1. Summary of data on the drainage areas of the Westbury and Syosset recharge basins.-..-

2. Summary of data on the Westbury and Syosset recharge basins .

3. Selected values of rainfall and inflow for Westbury and Syosset recharge basins derived from trend lines in figures 10 and 11

4. Rainfall, inflow, and average infiltration rates for selected storms in 1967 at the Westbury recharge basin. 


\section{GLOSSARY OF SYMBOLS AND TERMS}

$A \quad$ Cross-sectional area of flow, in square feet.

$D$ Hydraulic depth in feet; $D=A / T$. Also used as pipe diameter, in feet.

$d \quad$ Depth of water, in feet.

$E \quad$ Specific energy, in feet; the energy per pound of water at any section of a channel measured with respect to the channel bottom; $E=d+V^{2}$.

F Froude number; a dimensionless ratio of inertia forces to gravity forces; $\boldsymbol{F}=\mathrm{V} / \sqrt{g D}$.

$g \quad$ Acceleration of gravity, in feet per second per second.

Invert The lowest point on the internal cross section of a conduit.

$n \quad$ Coefficient of channel roughness; Manning's " $n$ ", in $\mathrm{ft}^{1 / 6}$.

$Q \quad$ Discharge, in cubic feet per second.

$R \quad$ Hydraulic radius, in feet; the cross-sectional area divided by the length of the part of the stream in contact with its containing conduit (wetted perimeter).

Reach A segment of stream length parallel to flow.

$S \quad$ Slope of water surface, channel bottom, and (or) energy line, in feet per foot.

$T \quad$ Channel width, in feet.

$V \quad$ Velocity, in feet per second.

$\Delta \quad$ Net incremental change. 
and Suffolk Counties (the other two counties on the island) are about 290 and 920 square miles, respectively; these counties had a combined population of about 2.5 million people in 1965 .

Although the New York City part of Long Island derives most of its water supply from surface-water sources in the Delaware and Hudson River basins (mainly in upstate New York), both Nassau and Suffolk Counties derive their entire water supply from wells tapping an extensive underlying ground-water reservoir. Because of present large demands on the groundwater system, particularly in Nassau and Suffolk Counties, and because of the prospect of increased demands as Long Island continues to develop rapidly, knowledge about the hydrologic system-with special emphasis on water conservation and management-is a matter of vital concern to the present population and to the millions of people who will depend on ground-water reserves in the future.

Considerable information is available about the water resources of Long Island as a result of more than 30 years of study by the U.S. Geological Survey in cooperation with New York State and county agencies. Although those studies meet many of the needs for data on specific water problems, better quantitative information about the islandwide hydrologic system and the relations and interactions among the various components of the system is needed for water management. To provide that water information, a comprehensive waterbudget study presently is being made by the Geological Survey in cooperation with the New York State Department of Conservation, Division of Water Resources; Nassau County Department of Public Works; Suffolk County Board of Supervisors; and Suffolk County Water Authority.

The major objectives of the water-budget study are: (1) to summarize and interpret pertinent existing information about the hydrologic system of Long Island and (2) to fill several gaps in the knowledge of the hydrologic system. The results of these studies are being published in a series of coordinated reports. In some of the reports, information is developed for all of Long Island; in others, the primary area of concern is limited to Nassau and Suffolk Counties.

\section{PURPOSE AND SCOPE OF THIS REPORT}

Direct runoff on Long Island has increased as a result of urban development-specifically, as a result of the construction of impervious surfaces, such as streets, parking lots, and buildings. The increased runoff and the method of disposing of the runoff has had a signifcant impact on the hydrologic system of the island.
Two major methods of storm-water disposal are presently used in Nassau and Suffolk: Counties: (1) discharge through storm drains directly into streams which convey storm flow rapidly into tr 9 adjacent bays and the ocean and (2) discharge through storm drains into nearby open pits (called recharge basins or sumps). Direct runoff to recharge basins, the subject of this report, is pertinent to any comprehensive analysis of the Long Island hydrologic system because the bulk of this runoff recharges the ground-water reservoir. Direct runoff to streams is the subject of another study in this report series (Seaburn, 1969).

The study described in this report was concerned with two recharge basins in Nassau Courty. The major objective of the study was to define the rainfall-inflow relations for each of the two basins, inc'uding the time of travel of runoff to the basins. Other items studied were: (a) the rate of infiltration of the inflow through the bottom and sides of one of the basins and (b) the rate of movement of water from one of the basins to the water table.

\section{PREVIOUS STUDIES}

Artificial ground-water recharge on Jong Island has been described by several authors, including Leggette and Brashears (1938) ; Brashears (1941, 1953) ; Johnson $(1948,1955)$; Parker, Cohen, and Foxworthy (1967); and Cohen, Franke, and Foxworthy (1968). Most of these authors have been concern $2 d$ with the role of recharge wells on Long Island or have presented a broad overview of the subject of artificial recharge on Long Island. Several other authors have discussed recharge basins in moderate detail and have estimated recharge rates for several basins (Brashears, 1946; Welsch, 1949; Parker and others, 1967). The most pertinent quantitative study of recharge kasins on Long Island to date (1968) was made by Brice, Whitaker, and Sawyer (1956).

\section{ACKNOWLEDGMENTS}

The author is grateful to numerous personnel of the Nassau County Department of Public W'orks, especially to Mr. Emmett Bowker, for helping to chose appropriate basins for the study, and to Mr. Charles Kirstner, who supervised the drilling of the water-table observation well. Lockwood, Kessler and Bar+lett, consulting engineers, supplied the aerial photographs.

The report was prepared under the irnmediate supervision of Bruce L. Foxworthy, former hydrologist in charge, Mineola subdistrict, and his siccessor, Philip Cohen, and under the general direction of Garald G. Parker, District chief, New York Dis'rict. 
HYDROLOGY AND SOME EFFECTS OF URBANIZATION ON LONG ISLAND, NEW YORK

\section{PRELIMINARY RESULTS OF HYDROLOGIC STUDIES AT TWO RECHARGE BASINS ON LONG ISLAND, NEW YORK}

\section{By G. E. Seaburn}

\section{ABSTRACT}

More than 2,000 recharge basins on Long Island are used to dispose of storm runoff from residential and industrial areas and highways. Two of these basins have been instrumented to measure the response time of runoff generated from a rainfall event and to study inflow patterns and the infiltration rates of the selected basins.

The time lag recorded at the Westbury test basin from the start of rainfall to the start of inflow ranged from 5 to 20 minutes. The time lag from the beginning of inflow to the initial response of the basin-stage recorder located about 120 feet from the discharging culvert ranged from 10 to 20 minutes. The time lag from the start of rainfall to the initial rise in the water table was between 2 and 8 hours.

The ratio of storm-water inflow to rainfall at the Westbury basin ranged from 0.08 to about 0.20 , and the average ratio for more than 1 year of record was about 0.14 . The ratio of stormwater inflow to rainfall at the Syosset basin ranged from 0.02 to 0.15 , and the average ratio for more than 1 year of record was about 0.10 . The average ratio of storm-water inflow to rainfall closely approximates the ratio of paved street area to total drainage area of both basins.
The estimated average annual volume of ground-water re. charge resulting from inflow to the basins and subsequent perco. lation to the underlying water table in 1967 was 7.5 acre-feet for the Westbury recharge basin and 10 acre-feet for the Syosset recharge basin.

The average infiltration rate at the Westbury recharge basir for 12 storms during the summer and fall of 1967 was 211 gallons per day per square foot.

\section{INTRODUCTION}

\section{PURPOSE AND SCOPE OF THE WATER-BUDGET STUDY}

Long Island, which extends from the southeasterr part of the mainland of New York State east-northeastward about 120 miles into the Atlantic Ocean, has a total area of about 1,400 square miles (fig. 1). Two boroughs of New York City (Kings and Queens Counties) occupy slightly less than 200 square miles of the western part of the island, and have a combined population of about 4.5 million people. The areas of Nassau

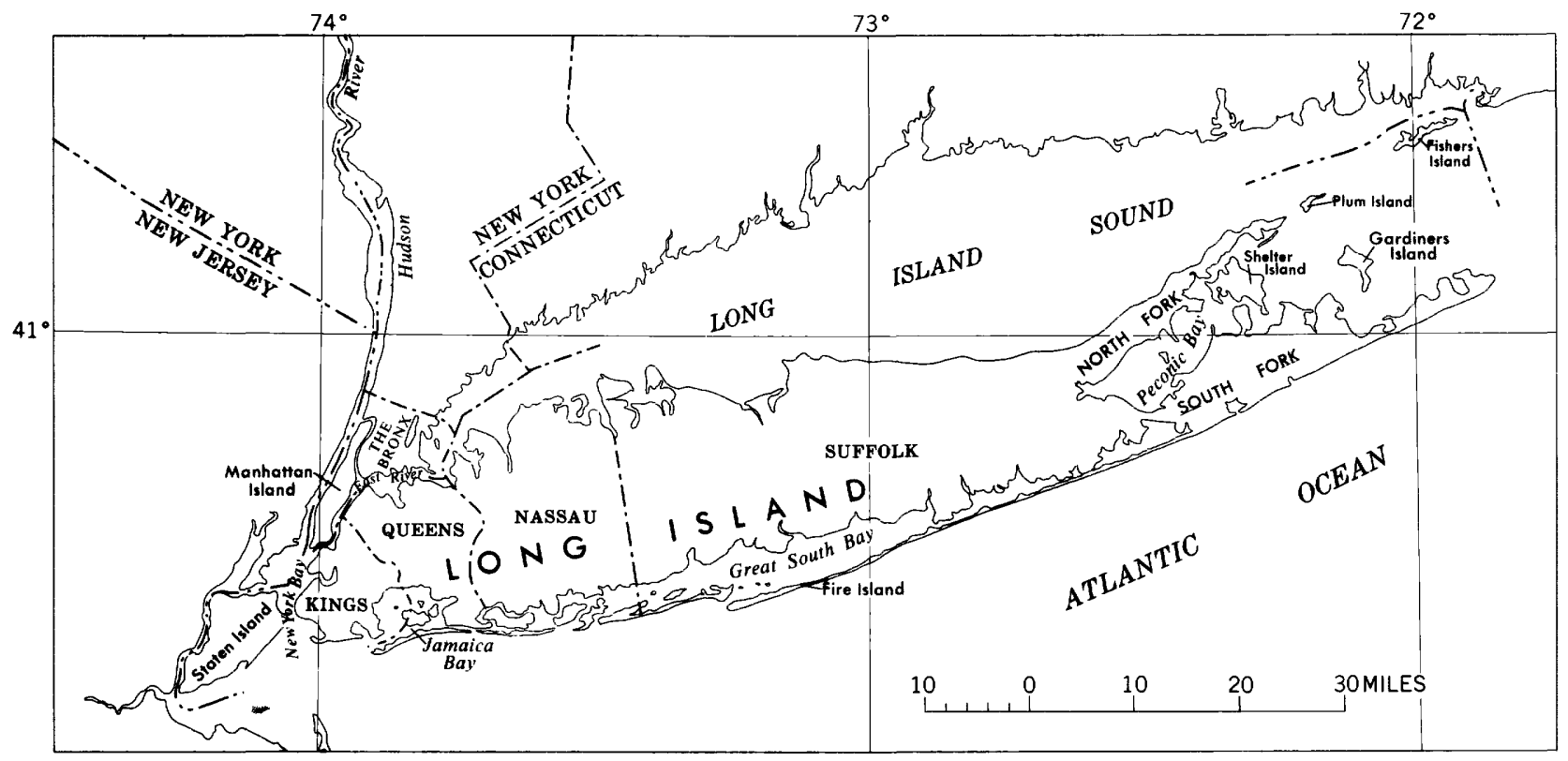

Frgure 1.-Location and general geographic features of Long Island. 


\section{USE AND GENERAL DESCRIPTION OF RECHARGE BASINS ON LONG ISLAND}

In 1935, as a result of a long-range drainage plan developed by Welsch (1935), the Nassau County Sanitation Commission decided to develop a system of short storm-sewer lines terminating in open basins or pits (commonly referred to as recharge basins) to dispose of most of the storm runoff in the county instead of discharging the runoff directly into streams or into the tidewaters of the Atlantic Ocean and Long Island Sound. This decision was made partly on the assumption that in much of Long Island this system would be more economical than the alternative of building long trunk sewers that discharged into streams or tidewater.

Recharge basins on Long Island are unlined pits (fig. 2) of various shapes and sizes which are excavated below land surface, mostly in moderately to highly permeable sand and gravel deposits of glacial outwash. The basins range in area from about 0.1 to 30 acres and average about 2 acres. Their average depth is about 10 feet, but some are about 25 feet deep. Generally, recharge basins are used only where the water table is sufficiently deep to remain below the floor of the basin all, or at least most of the time. Therefore, only a few recharge basins are located in nearshore areas, where the water table is within a few feet of the land surface.

About 500 basins are maintained in Nassau County mainly by the Nassau County Department of Public Works. A few are also maintained by the towns and some by private owners. Suffolk County has about 1,400 basins, most of which are maintained by the towns. In addition, about 135 basins (50 in Nassau County and about 85 in Suffolk County) are maintained by the New York State Department of Highways.

The basins can be grouped into two general typesthose with, and those without, overflow structures. However, most of the basins are equipped with some type of overflow structure - that is, when the capacity of the basin is exceeded, overflow water is carried by pipes, flumes, or gutters to another recharge basin or to a nearby stream.

Design criteria for recharge basins on Long Island have evolved for the most part on a trial-and-error basis during the last 30 years. At present, the criteria used

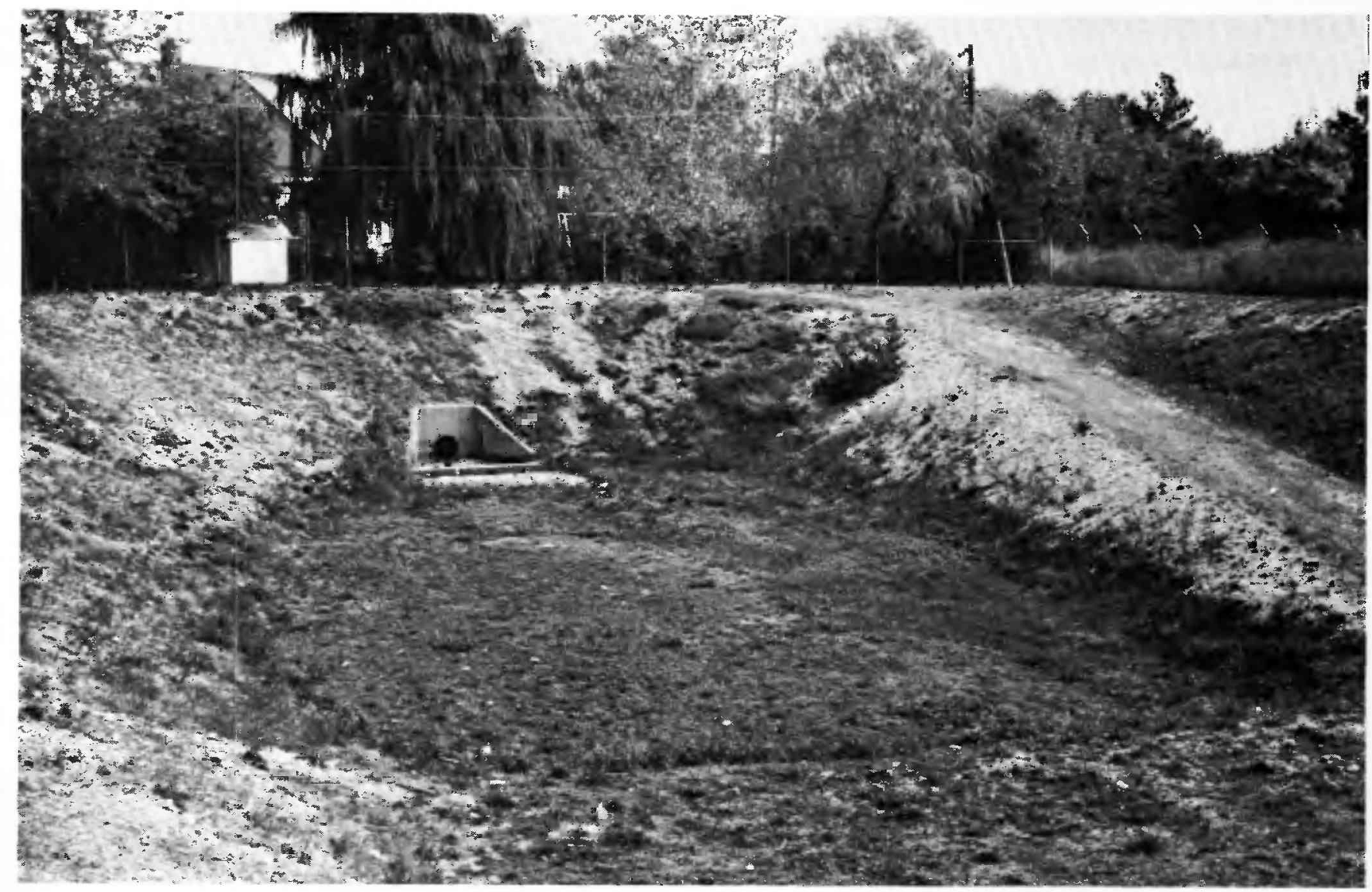

Fraure 2.-Typical recharge basin in Nassau County. 
to design the size of a recharge basin in Nassau County are those that have been established by the Department of Public Works. Two major criteria are used in Nassau County to design a basin that has an overflow structure (or structures). First, the required size (volume) of the basin below the overflow elevation is estimated by multiplying (a) the volume of water equivalent to 5 -inches of rainfall on the total drainage area of the basin by (b) a factor ranging from 40 to 90 percent. The factor selected is based on conditions in the drainage area, such as land slope and percentage of area occupied by streets and parking lots. A runoff factor of 40 percent is used in most residential areas, and the factor used in industrial areas is as much as 90 percent to allow for the usually higher proportion of impervious surfaces in these areas. Second, the elevation of the overflow structure must not be more than 10 feet above the floor of the basin. Infiltration into the floor and sides of the basin is neglected in the design, and this provision results in an additional factor of safety.

Only a few basins are built without overflow structures; these are termed "dead-end" basins. Because the operation of these basins varies widely, depending upon local conditions, firm regulations regarding their size have not been established.

All recharge basins in Nassau County have two or more levels. The lower level (the floor of the basin) is at the elevation of the invert of the inflow pipes, and this level acts as a settling pool to collect inflowing sediment and trash. The higher level, commonly about 2 feet above the floor, serves as a platform for maintenance work when the lower level is flooded The higher level also facilitates infiltration of water into the ground inasmuch as it remains comparatively free of sediment.

The design criteria used to construct recharge basins in Suffolk County are similar to those used in Nassau County. In Suffolk County, however, the construction of recharge basins is regulated mostly by the towns rather than by the county.

\section{LOCATION AND DESCRIPTION OF TEST BASINS}

The two recharge basins that were studied during the investigation described in this report are in residential areas that are typical of much of surburban Nassau County. One basin is in the village of Westbury; the other is about 7 miles northeast in the village of Syosset (fig. 3). The drainage area of the Westbury recharge basin is about 15.0 acres; the basin is rectangular in shape (fig. 4), and the average land-surface gradient is about 13 feet per mile to the south. The drainage area of the Syosset recharge basin is about 28.8 acres; this basin also is rectangular in shape (fig. 5), and the land-surface gradient is about 20 feet per mile to the south. Pertinent information regarding the drainage areas of the Westbury and Syosset recharge basins is summarized in table 1. Additional information about the Westbury and Syosset recharge basins is given in table 2.

TABLE 1.- Summary of data on the drainage areas of the Westbury and Syosset recharge basins

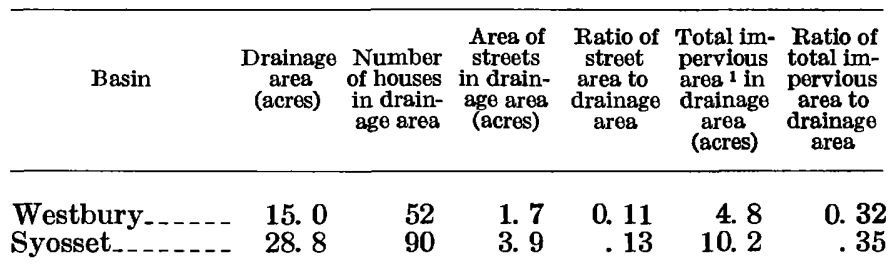

1 Total impervious area includes streets, driveways, sidewalks, and roofs.

TABLE 2. - Summary of data on the Westbury and Syosset recharge basins

\begin{tabular}{lcccr}
\hline Basin & $\begin{array}{c}\text { Area } \\
\text { (acres) }\end{array}$ & $\begin{array}{c}\text { Depth } \\
\text { (feet) }\end{array}$ & $\begin{array}{c}\text { Volume 1 } \\
\text { (million } \\
\text { gallons) }\end{array}$ & $\begin{array}{c}\text { Diameter of } \\
\text { inflow pipe } \\
\text { (inches) }\end{array}$ \\
\hline Westbury & 0.5 & 12 & 0.71 & 24 \\
Syosset__- & 1.0 & 14 & 2.09 & 30
\end{tabular}

1 Below the overflow elevation.

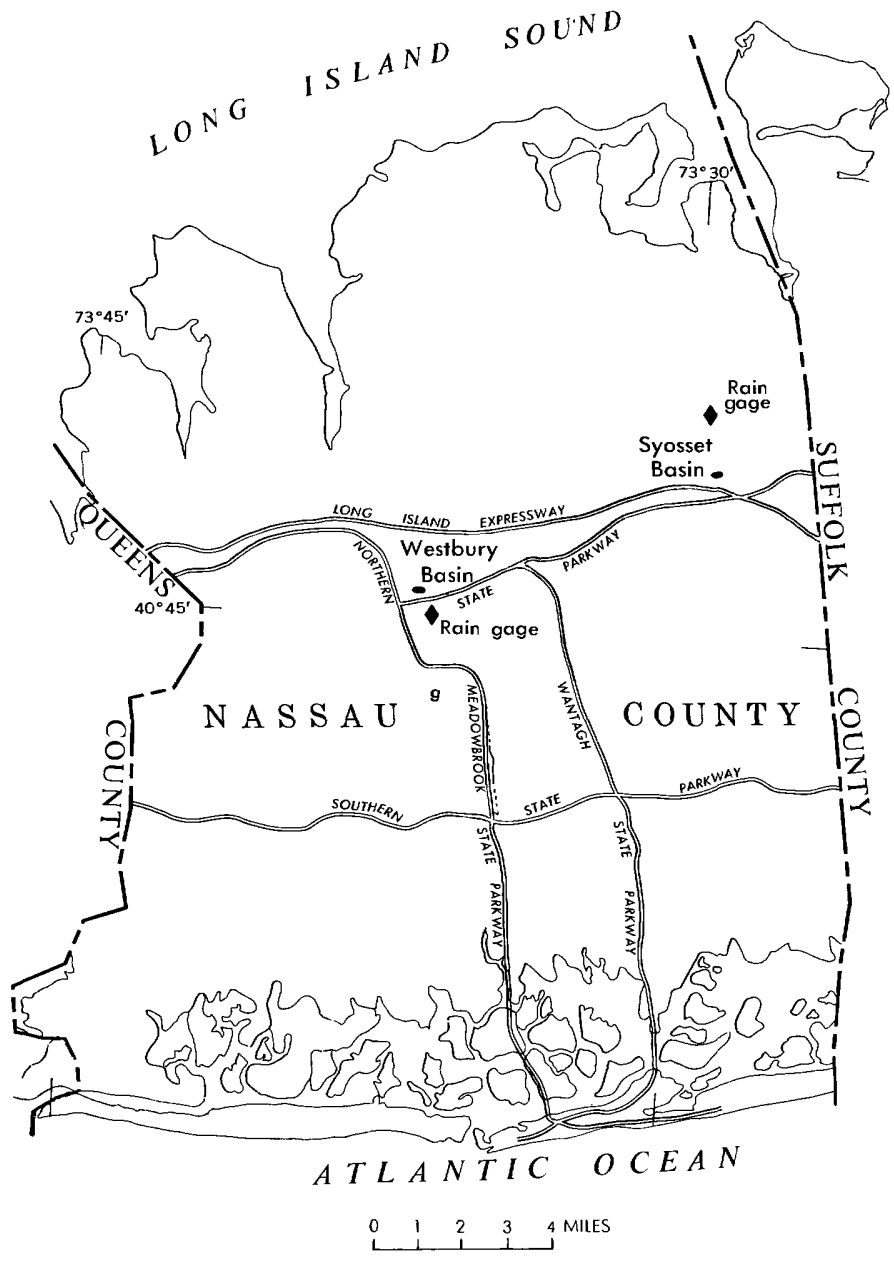

FIGURE 3.-Location of Westbury and Syosset artificial recharge basins and rain gages in Nassau County. 


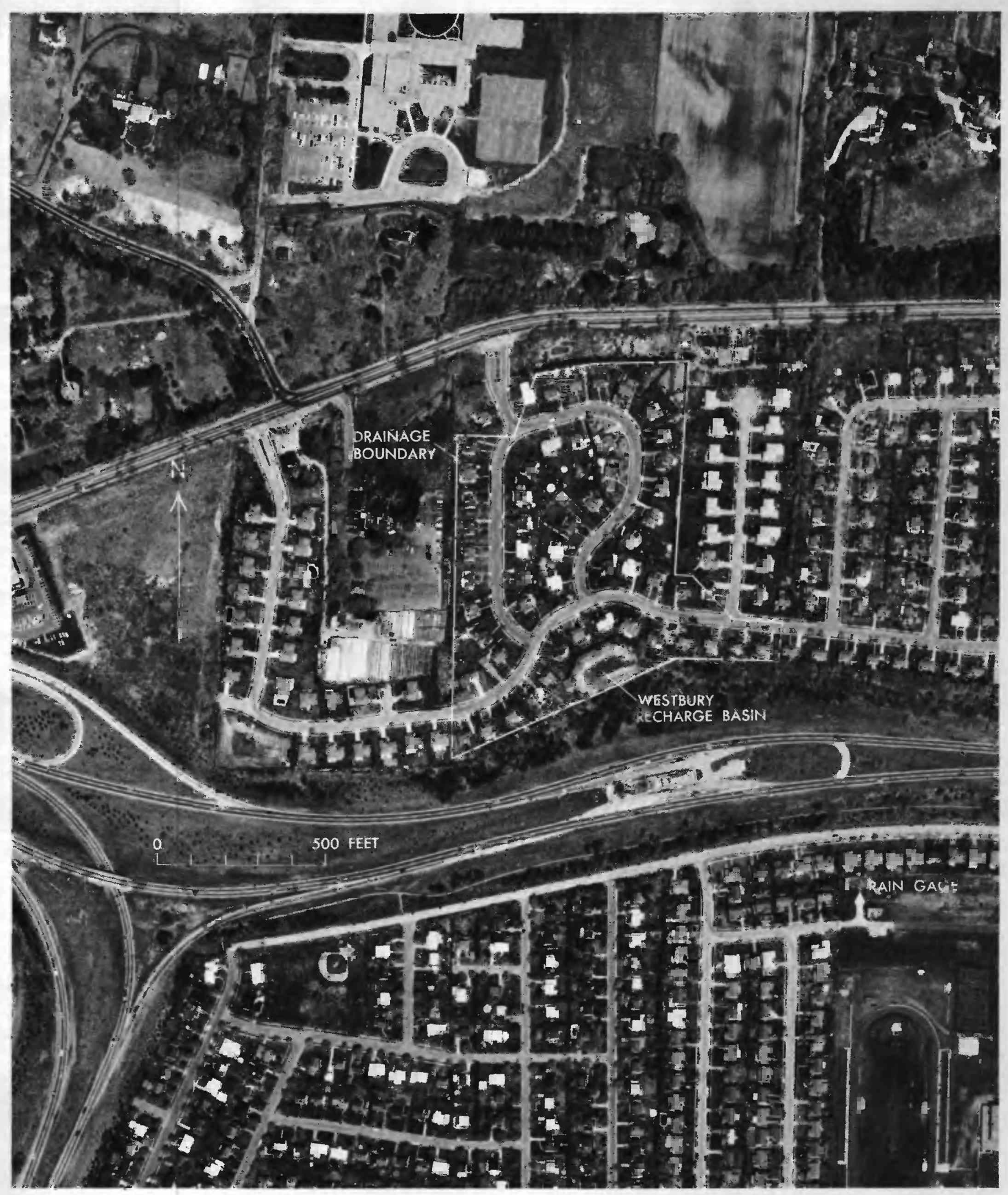

FIGURE 4.-Aerial photograph of the Westbury recharge basin and its drainage area. Photograph by Lockwood, Kessler, and Bartlett. 


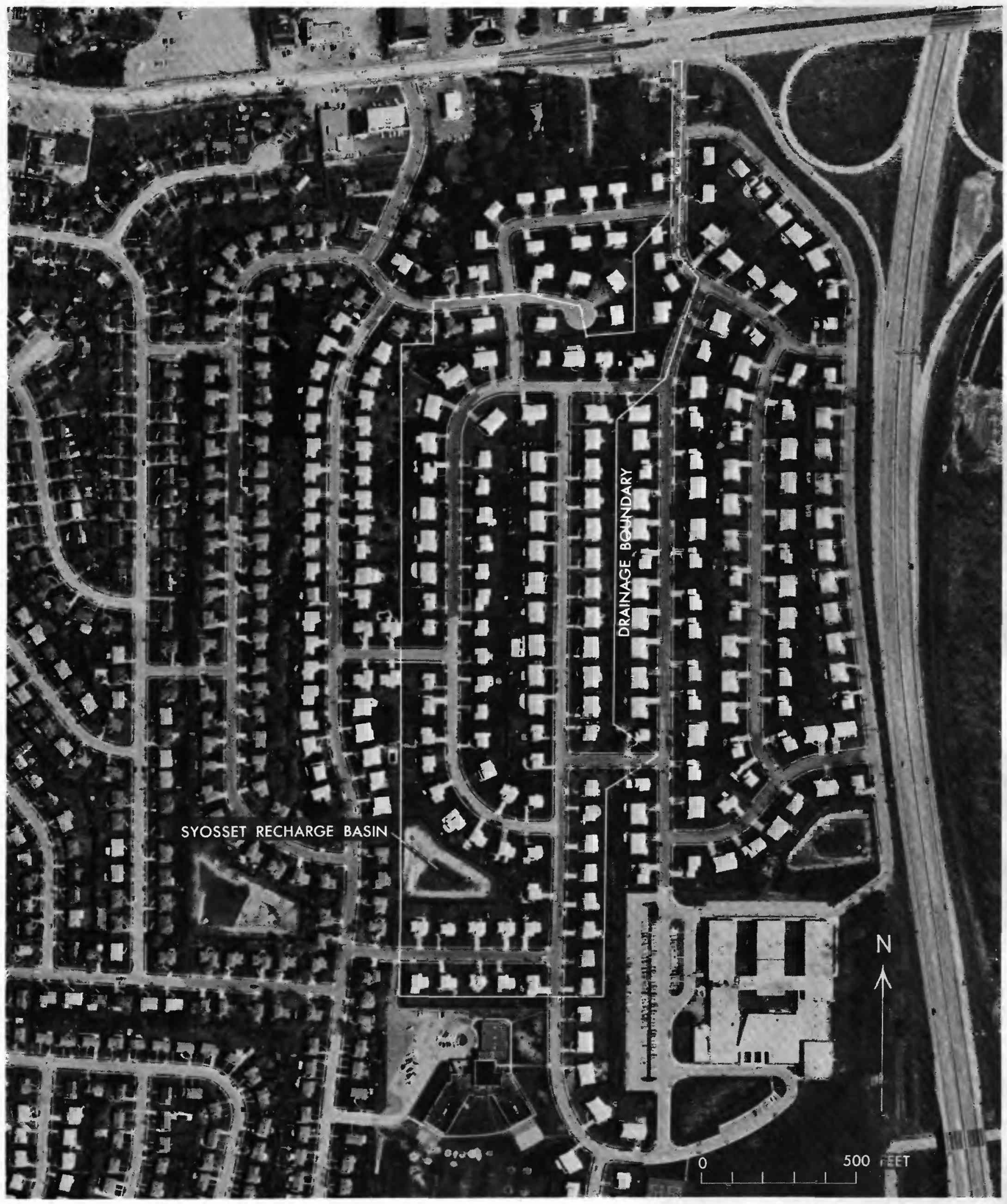




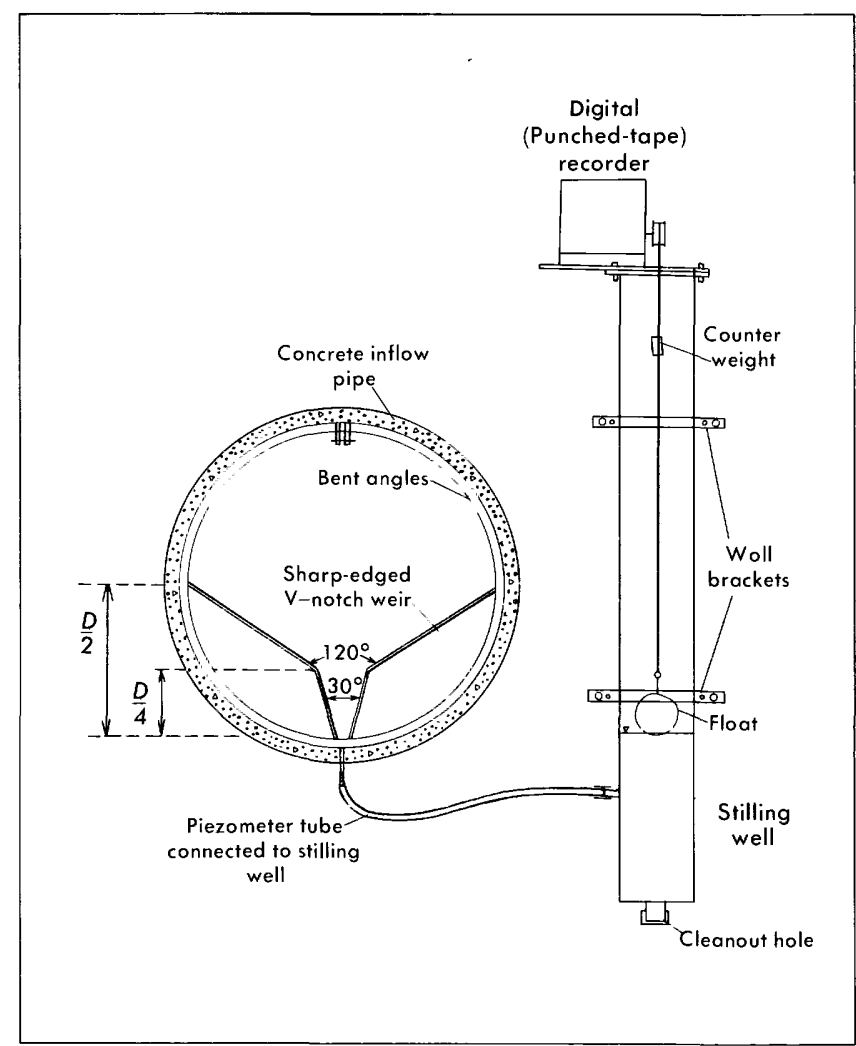

FIaURE 7.-Sketch of inflow-measuring apparatus located in manhole nearest each recharge basin.

tends to a height equal to about one-half the diameter. The weir was cut from $1 / 4$-inch stainless-steel plate, and the edges of the weir were beveled to a sharp edge.

The piezometric head on the weir is measured through a vertical tube, three-fourths of an inch in diameter, inserted flush with the inside surface of the pipe 3 inches upstream from the weir (fig. 6). The tube transmits the head on the weir to a nearby stilling well which is equipped with a water-level recorder. The recorder was set to record (punch) every 5 minutes.

Weighing-bucket recording rain gages were installed as close to the recharge basins as practical. The Westbury gage is about 300 yards southeast of the basin, and the Syosset rain gage is about 2,300 yards north of the basin (fig. 3). Small plastic rain gages were also installed in each basin.

The water-table observation well at the Westbury basin is 4 inches in diameter and is equipped with a stainless-steel screen that is set in coarse sand and gravel about 50 feet below the floor of the basin. The depth to the water table was about 35 feet in 1967.

The characteristics of the inflow structures at the basins and the somewhat unusual design of the weirs resulted in the need to use detailed and moderately complex procedures to calibrate the weirs. These pro- cedures are described in the appendix to this report ( $p$. C14).

\section{MEASUREMENT OF BASIN STPRAGE}

A detailed topographic survey of th 9 Westbury recharge basin was made to define the ralations between depth of water in the basin, as measured by the basinstage recorder, and water-surface ares, and volume of storage in the basin. These relations are shown in figure 8. The small increase in the water-surface area between the values of water depth of $1.0-2.0$ feet is the result of the two levels of the Westbury recharge basin.

\section{RESULTS OF THE STUDY}

Precipitation data for more than 75 rainfall events (ranging from about 0.10 to 5 inches) and concurrent inflow to the Westbury and Syosset recharge basins were obtained from midsummer 1966 to January 1968. Data on basin stage and fluctuations of the water table were obtained at the Westbury recharge basins for about 20 rainfall events from June $: .967$ to January 1968.

\section{TIME RESPONSE OF THE STSTEM}

In general, the time lag from the berinning of rainfall to the beginning of inflow to the basin (measured at the weir) ranged from 5 to 20 minutes. This time lag was caused mainly by filling of depressions in the gutters, inlets, and pipes upstream from the weir. The time lag between measurable inflow at the weir in the Westbury basin and the initial resporse of the basinstage recorder ranged from 10 to 20 minutes. This lag reflected the time required for the water to flow from the weir to the basin-stage recorder, which is at the lowest elevation on the basin floor abont 120 feet from

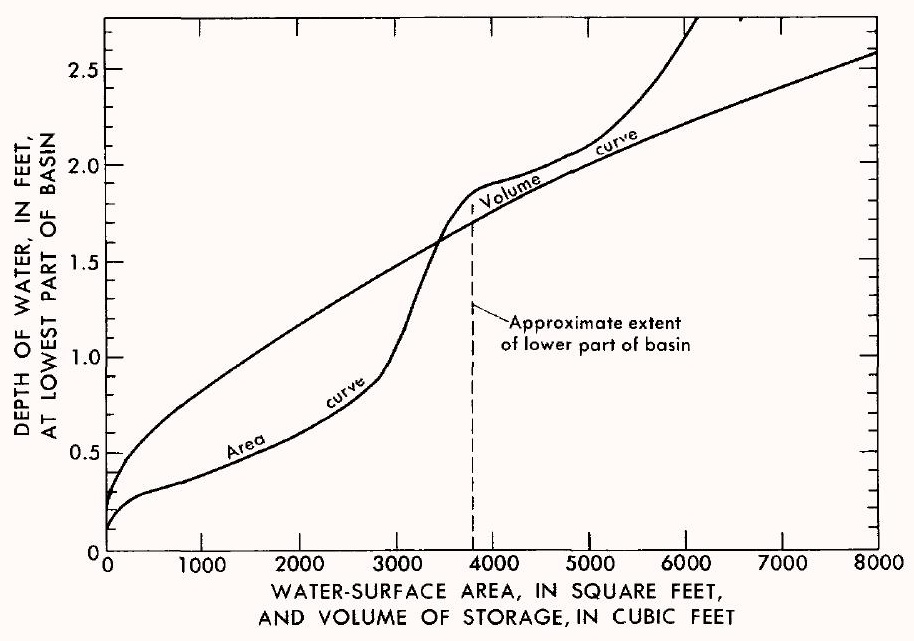

Froure 8.-Relations between water depth, water-surface area, and volume of storage for the Westbury recharge basin. 
the weir. The time lag between the start of rainfall and the initial rise of the water table ranged from 2 to 8 hours.

Many factors were responsible for the time lags described in the preceding paragraph; however, the most significant probably were the intensity and magnitude of the rainfall and antecedent soil-moisture conditions.

An example of the relations between rainfall, inflow, basin storage, and fluctuations of the water table at t $\mathrm{t}$ ? Westbury recharge basin is shown in figure 9. Total rainfall during the storm, which lasted for about 3 hours, was about 1.45 inches. During the first 20 minutes, the intensity of the storm was more than 1 inch per hour. Inflow to the basin was first measured at the weir 5 minutes after rainfall began. Total inflow was equivalent to 0.35 inch in the entire drainage area, or about
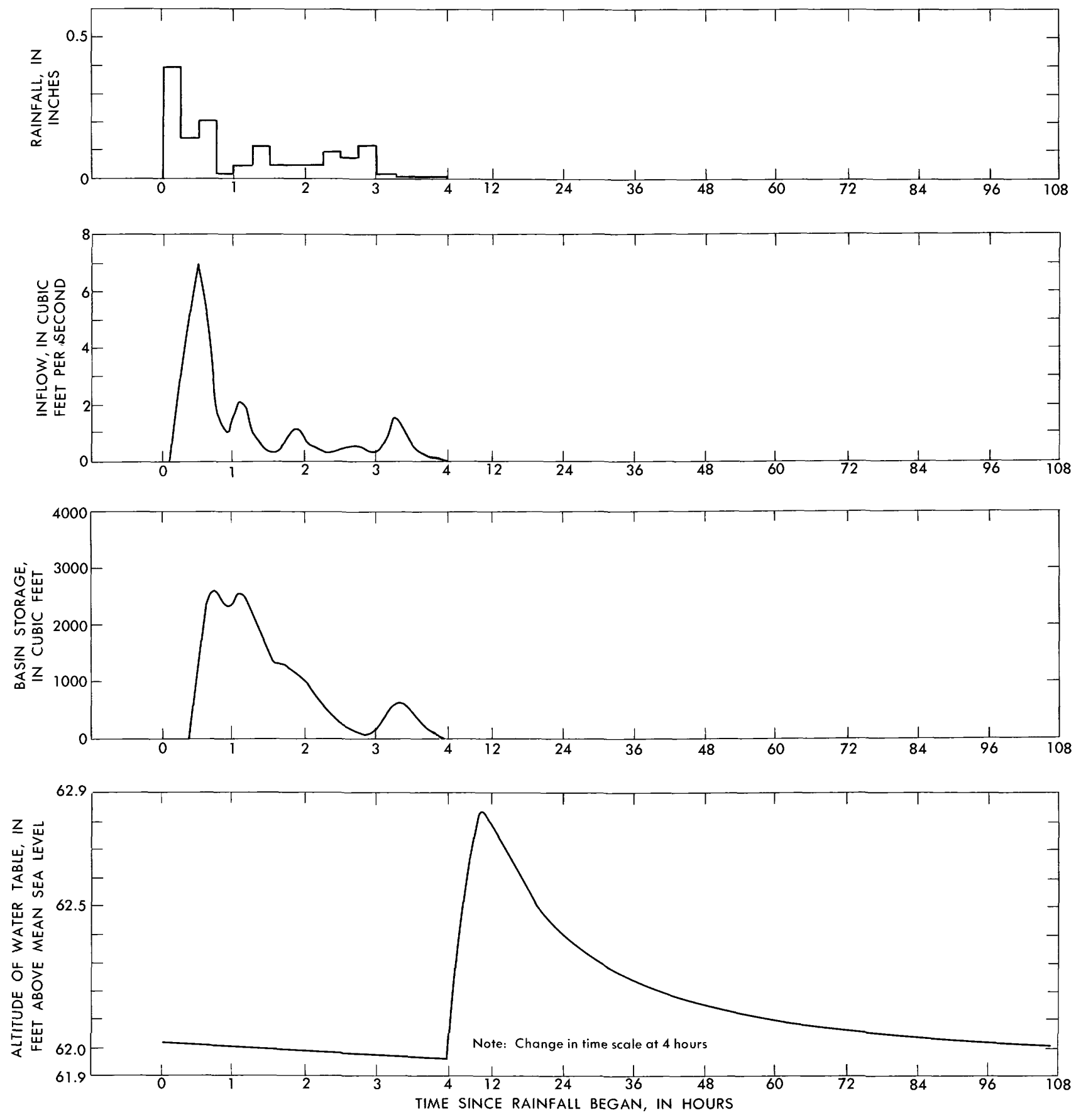

Figure 9.-Rainfall, inflow, basin storage, and water-table elevation for a storm on October 18, 1967, at the Westbury recharge basin. 
24 percent of the total rainfall. Standing water was measured at the basin-stage recorder about 15 minutes after the beginning of rainfall and about 10 minutes after the inflow was first noted at the weir. The water table began to rise about 4 hours after rainfall began.

\section{RAINFALL-INFLOW RELATIONS}

The relations between rainfall and inflow (expressed in inches of rainfall on each drainage area) for the Westbury and Syosset recharge basins are shown in figures 10 and 11, respectively. The points in both figures are widely scattered because, in addition to the total amount of rainfall, inflow also is related to the duration, intensity, time distribution, and direction of movement of a storm, antecedent soil-moisture conditions, and several other factors. The scatter of points for the Syosset basin (fig. 11) is larger than that for the Westbury data, especially for the smaller storms. This greater scatter may partly be a result of the fact that the Syosset drainage area has a drainage-collection network that includes nine open-bottom street inlets as compared to only one open-bottom inlet in the Westbury drainage area. Each of these street inlets acts as a small recharge basin, thereby disposing of some runoff before it reaches the

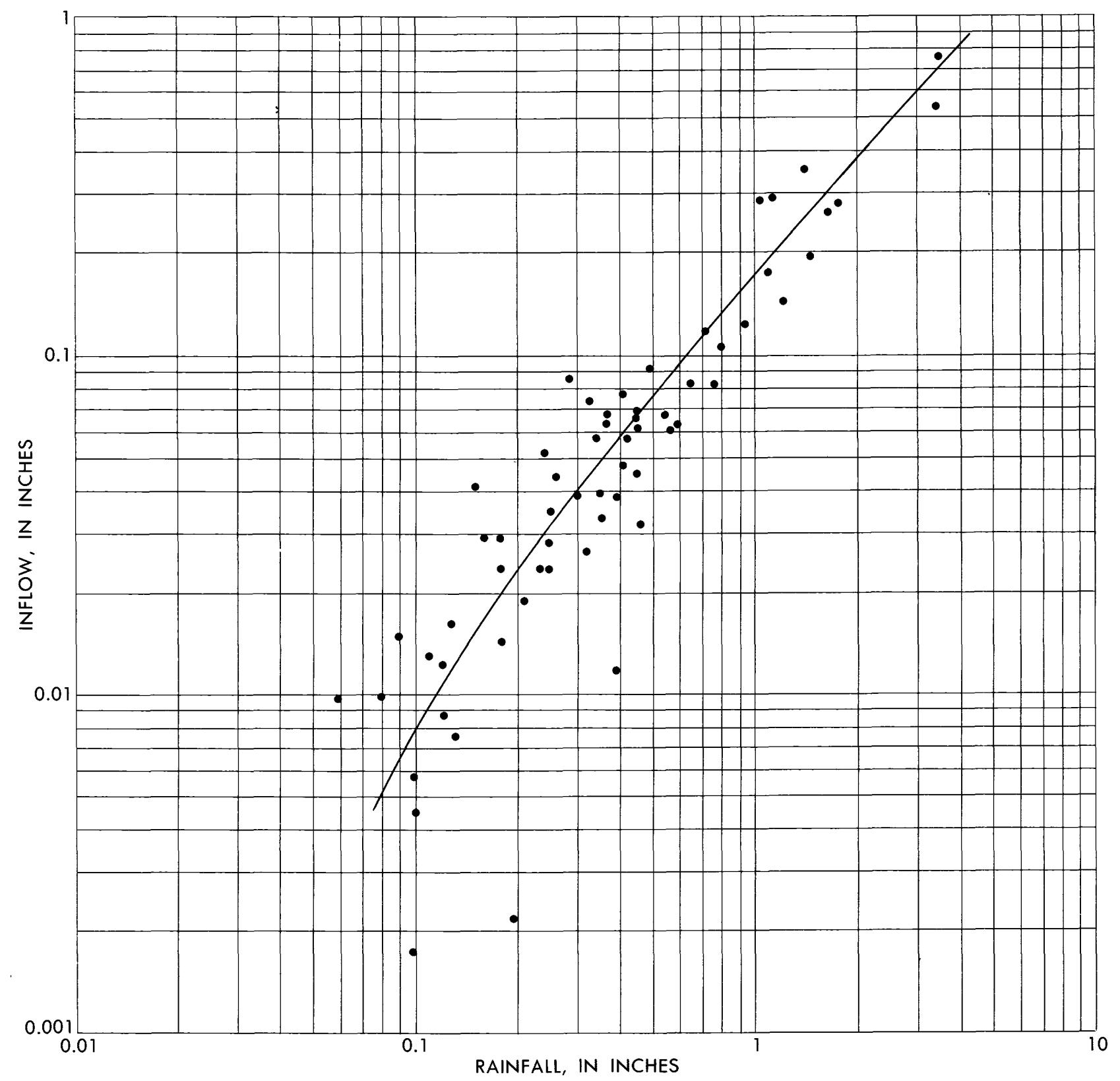

FTaURe 10.-Relation between rainfall and inflow to the Westbury recharge basin, 1966-67. 
main recharge basin. This factor probably is responsible for some of the scatter of all the data obtained at the Syosset recharge basin, but it likely had a greater effect during the smaller storms.

Table 3 gives some representative values and selected ratios of inflow to rainfall calculated from the trend lines in figures 10 and 11. These data show that both inflow and the ratio of inflow to rainfall increase as total rainfall increases. Also, the ratio of inflow to rainfall is larger at the Westbury recharge basin than at the Syosset basin. The difference between the ratios of inflow to rainfall for Westbury and Syosset (table 3), which is about 5-8 percent, probably is largely a measure of tr 9 effect of the previously mentioned street inlets in tra Syosset drainage area on reducing inflow to the Syosset basin.

The average measured ratio of inflow to rainfall in 1967 was 0.14 at the Westbury basin and 0.10 at the Syosset basin. This closely approximates the ratio of street area to the total drainage area-that is, 0.11 for the Westbury drainage area and 0.13 for the Syosset drainage area (table 1). This close approximation suggests that in small suburban drainage areas with similar infiltration characteristics, the volume of runoff is related

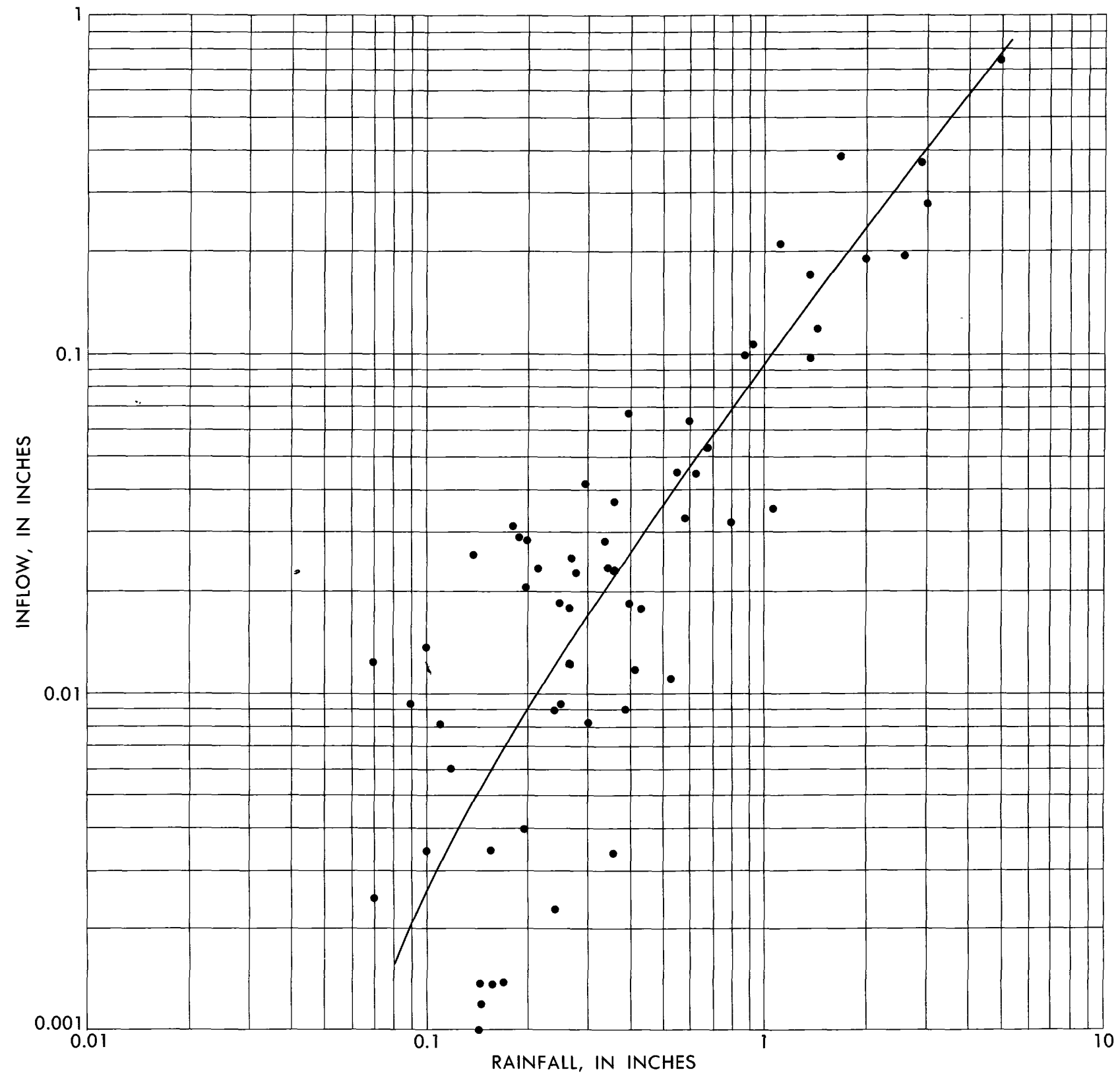

Figure 11.-Relation between rainfall and inflow to the Syosset recharge basin. 1966-67. 
to the proportion of street area in the drainage area. Of course, for storms with large magnitudes or high intensities, additional areas, such as driveways, sidewalks, and lawns, also contribute runoff by overflowing onto the streets.

TABLE 3.-Selected values of rainfall and inflow for Westbury and Syosseet recharge basins derived from the trend lines in figures 10 and 11

\begin{tabular}{|c|c|c|c|c|}
\hline \multirow[b]{2}{*}{$\begin{array}{l}\text { Rainfall } \\
\text { (inches) }\end{array}$} & \multicolumn{2}{|c|}{ Westbury recharge basin } & \multicolumn{2}{|c|}{ Syosset recharge basin } \\
\hline & $\begin{array}{c}\text { Inflow } \\
\text { (inches) }\end{array}$ & $\begin{array}{l}\text { Ratio of } \\
\text { inflow to } \\
\text { rainfall }\end{array}$ & $\begin{array}{l}\text { Inflow } \\
\text { (inches) }\end{array}$ & $\begin{array}{l}\text { Ratio of } \\
\text { inflow to } \\
\text { rainfall }\end{array}$ \\
\hline 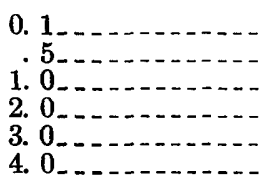 & $\begin{array}{r}0.008 \\
.076 \\
.18 \\
.39 \\
.60 \\
.81\end{array}$ & $\begin{array}{l}0.08 \\
.15 \\
.18 \\
.19 \\
.20 \\
.20\end{array}$ & $\begin{array}{r}0.0025 \\
.036 \\
.095 \\
.25 \\
.40 \\
.59\end{array}$ & $\begin{array}{l}0.02 \\
.07 \\
.10 \\
.12 \\
.13 \\
.15\end{array}$ \\
\hline
\end{tabular}

\section{INFILTRATION RATES AT THE WESTBURY BASIN}

Rates of infiltration through the bottom of the Westbury recharge basin were calculated from the inflow and basin-storage data using the continuity equation,

$$
\text { Infiltration }=\text { Inflow } \pm \triangle \text { Storage, }
$$

where the symbol, $\triangle$, indicates the net incremental change in storage. Evapotranspiration losses are believed to have been negligible and, therefore, these losses were neglected. A graph of the computed rate of infiltration at the Westbury basin for a storm on October 18,1967 , is shown in figure 12. The infiltration rate during this storm ranged from 10 to $510 \mathrm{gpd}$ per sq ft (gallons per day per square foot) and averaged $277 \mathrm{gpd}$ per sq ft.

The relation between depth of water and the infiltration rate at the Westbury recharge basin is shown in figure 13. The sequentially plotted points are average infiltration rates for 5-minute intervals. It is apparent that the depth of water in the basin and the infiltration rate are not closely nor directly related. Other factors that probably influence infiltration rates significantly, include antecedent soil-moisture conditions, water temperature, barometric pressure, and differences in permeability of the soil materials in different parts of the basin.

In a previous study, Brice, Whitaker, and Sawyer (1956) related infiltration rates to the depth of water in a recharge basin on Long Island. They also concluded that many factors affect infiltration rates, and that there was no simple relation between depth of water and infiltration rates.

Infiltration rates and other pertinent data for several storms in 1967 are given in table 4 . The average infiltration rate during these storms in the summer and fall of
1967 was 211 gpd per sq ft. The depth of water in the lowest part of the basin never exceeded 2 feet and rarely exceeded 1.5 feet.

Estimates of rates of infiltration by others have ranged widely. Brice, Whitaker, and Sawyer (1956) reported infiltration rates ranging from 20 to $400 \mathrm{gpd}$ per sq $\mathrm{ft}$ when the depth of water in the basin that they studied was artifically maintained at 1 foot. Welsch (1949) determined an average infiltration rate of $23 \mathrm{gpd}$ per sq ft for 14 recharge basins rangir $g$ in size from 2 to 9 acres. The depth of water in there basins ranged from 0.5 to 9 feet.

\section{GROUND-WATER RECHA]PGE}

Virtually all the water that enters tre Westbury and Syosset recharge basins infiltrates into the ground within a few hours and almost always within a day after water first flows into the basin. Accordingly, the amount of inflow consumed by evapotranspiration is negligible; so for practical purposes it can be assumed that all, or almost all, the inflow to these two kasins ultimately recharges the ground-water reservoir. On the basis of this assumption and using the approximate relations between inflow to the basins and precipitation described

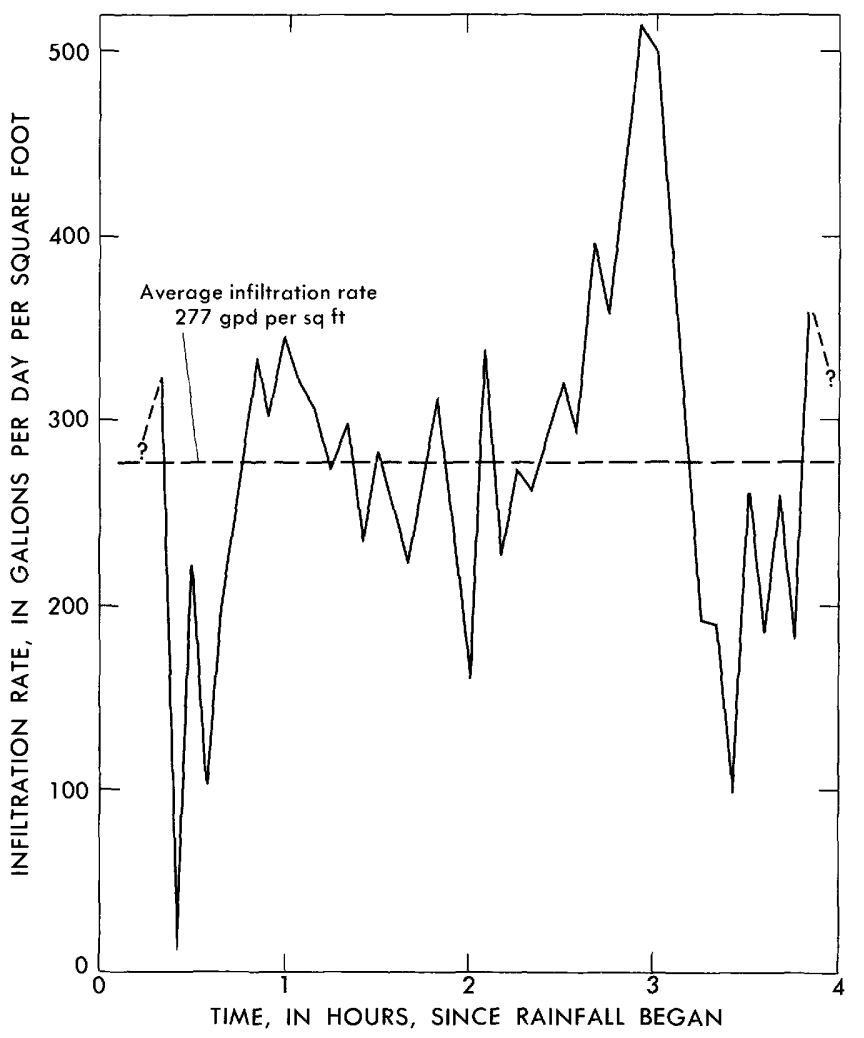

Figure 12.-Average infiltration rates calcrlated for 5-minute intervals at the Westbury recharge basin for the storm on October 18, 1967. 


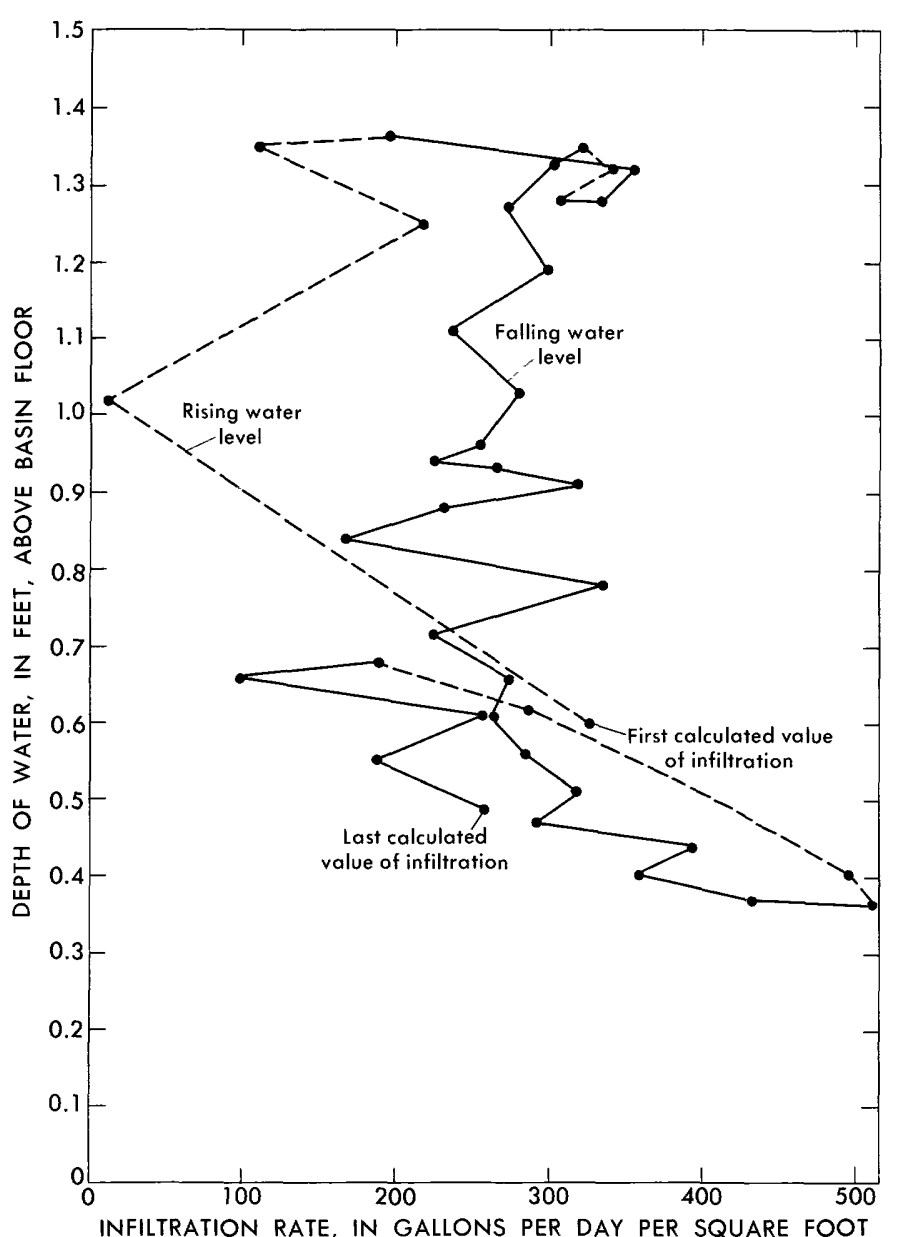

Figure 13.-Relation between depth of water and average infiltration rate calculated for 5-minute intervals in the Westbury recharge basin, during the storm of October $18,1967$.

in the previous paragraphs, the estimated ground-water recharge in 1967 resulting from inflow to the Westbury and Syosset basins was 7.5 and 10 acre-feet, respectively.

Average precipitation in the area of these recharge basins is about 44 inches (Cohen and others, 1968, p. 31). Because 1967 was a year of near-average precipitation (about 42 in.), runoff for these developed drainage areas probably also was near average during that year. Therefore, the estimates of ground-water recharge are assumed to be roughly equal to the average annual groundwater recharge resulting from inflow to the two basins.

\section{SUMMARY AND CONCLUSIONS}

More than 2,000 recharge basins on Long Island are used to dispose of storm runoff from residential and industrial areas and highways. Two of these basins have been instrumented to collect data on inflow and time of response from a rainfall event. Inflow to both basins was determined by recording the flow over a compound $V$-notch weir placed in the mouth of the inflow pipe to the manhole nearest each recharge basin. At one basin the depth of water in the basin was recorded simultaneously with inflow to measure the change in basin storage and water-surface area. Average rates of infiltration were calculated from this data. An observation well was installed to monitor the fluctuations of tra water table resulting from the influx of the recharco water.

The time lag recorded at the Westbury test basin, from the start of rainfall to the start of inflow, ranged from 5 to 20 minutes. The time lag from the beginning of inflow to the initial response of the basin-stage recorder ranged from 10 to 20 minutes. The time lag from the start of rainfall to the initial rise in the water table was between 2 and 8 hours.

The ratio of inflow to rainfall at the Westbury basin ranged from 0.08 to about 0.20 and averaged about 0.14 . The ratio of inflow to rainfall at the Syosset basin ranged from 0.02 to 0.15 and averaged about 0.10 . Inflow to the Syosset basin was affected by numerous openbottomed street inlets which act as small rechargo basins, thus reducing the total amount of inflow thet reaches the basin.

The average ratio of inflow to rainfall closely approximates the ratio of street area to total area, which suggests that rainfall directly on the streets provides a large proportion of the direct runoff.

The average infiltration rate at the Westbury basin determined from storms during the summer and fall of 1967 and 211 gpd per sq ft. The Westbury recharge basin seems to be typical of most well-operating basirs on Long Island. Accordingly, as a first approximation, this average rate of infiltration probably is a reasonabJe order of magnitude for other similar basins in the area.

TABLE 4.-Rainfall, inflow, and average infiltration rates for selected storms in 1967 at the Westbury recharge basin

\begin{tabular}{|c|c|c|c|}
\hline Date 1 & $\begin{array}{l}\text { Rainfall } \\
\text { (inches) }\end{array}$ & $\begin{array}{l}\text { Inflow } \\
\text { (inches) }\end{array}$ & $\begin{array}{l}\text { Average infil- } \\
\text { tration rati } \\
\text { (gallons pe" } \\
\text { day per } \\
\text { square foot) }\end{array}$ \\
\hline 1967 & & & \\
\hline 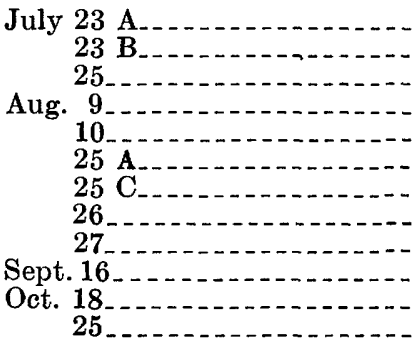 & $\begin{array}{r}0.13 \\
.18 \\
.42 \\
.42 \\
.15 \\
1.77 \\
.71 \\
.37 \\
.33 \\
.55 \\
1.45 \\
.60\end{array}$ & $\begin{array}{l}0.016 \\
.029 \\
.049 \\
.058 \\
.042 \\
.283 \\
.118 \\
.063 \\
.074 \\
.067 \\
.385 \\
.063\end{array}$ & $\begin{array}{l}209 \\
285 \\
145 \\
180 \\
173 \\
270 \\
186 \\
137 \\
242 \\
264 \\
277 \\
157\end{array}$ \\
\hline
\end{tabular}

Average

1 Capital letters represent the chronological order of two or more distinct storms occurring on the same day. 
The estimated ground-water recharge in 1967 was roughly 7.5 acre-feet for the Westbury basin and 10 acre-feet for the Syosset basin. This estimate probably is representative of the average annual recharge for these two recharge basins, inasmuch as 1967 was a year of near-average precipitation on Long Island, which, in turn, resulted in near-average runoff.

\section{REFERENCES CITED}

Brashears, M. L., Jr., 1941, Ground-water temperature on Long Island, New York, as affected by recharge of warm water: Econ. Geology, v. 36, no. 8, p. 811-828.

1946, Artificial recharge of ground water on Long Island, N.Y. : Econ. Geology, v. 41, no. 5, p. 503-516.

1953, Recharging ground-water reservoirs with wells and basins : Mining Eng., v. 5, p. 1029-1932.

Brice, H. D., Whitaker, C. L., and Sawyer, R. M., 1956, A progress report on the disposal of storm water at an experimental seepage basin near Mineola, N.Y.: U.S. Geol. Survey openfile report, 34 p., 22 figs., 2 pls.

Chow, V. T., 1959, Open-channel hydraulics : New York, McGrawHill Book Co., $680 \mathrm{p}$.

Cohen, Philip, Franke, O. L., and Foxworthy, B. L., 1968, An atlas of Long Island's water resources: New York State Water Resources Comm. Bull. 62, p. 30.

Johnson, A. H., 1948, Ground-water recharge on Long Island : Am. Water Works Assoc. Jour., v. 40, no. 11, p. 1159-1166. 1955, Conservation of ground-water on Long Island: Am. Water Works Assoc. Jour., v. 47, no. 4, p. 348-354.

Leggette, R. M., and Brashears, M. L., Jr., 1938, Ground water for air conditioning on Long Island, N.Y.: Am. Geophys. Union Trans., v. 19, pt. 1, p. 412-418.

Parker, G. G., Cohen, Philip, and Foxworthy, B. L., 1967, Artificial recharge and its role in scientific water management with emphasis on Long Island, N.Y. : Am. Water Resources Assoc., National Symposium on ground-water hydrology, San Francisco, Calif., Proc. p. 193-213.

Seaburn, G. E., 1969, Effects of urban development on direct runoff to East Meadow Brook, Nassau County, N.Y.: U.S. Geol. Survey Prof. Paper 627-B (in press).

Welsch, W. F., 1935, Comprehensive drainage plan for Nassau County, New York-summary report: Nassau County Sanitation Comm., 23 p.

1949, Conservation of ground-water resources, Nassau County, N.Y.: Water Works Eng., v. 102, no. 8, p. 708-710, 741-746.

\section{APPENDIX}

\section{PROCEDURES USED TO CALIBRATE THE WEIRS AT} THE WESTBURY AND SYOSSET RECHARGE BASINS

To calibrate the weirs at the Westbury and Syosset recharge basins, flow from nearby fire hydrants was measured volumetrically by two methods-before and after the water passed the weir. The first method involved determining the time required to fill two 55-gallon drums. The second method involved the construction of a temporary brick dam on the apron of the outlet structure in the recharge basin. This dam allowed nearly 1,000 gallons of water to be collected behind the dam in the outlet pipe and the bottom of the manhole.
Discharge was measured by determining the time required to fill this volume with water flowing over the weir under steady-flow conditions. The maximum flow that could safely be obtained from the fre hydrants was about $600 \mathrm{gpm}$ ( $1.34 \mathrm{cfs})$. The two different volumetric methods provided an adequate check on the discharge determinations. In all cases the difference between discharge measurements by the two methods was less than 1 percent.

During each of the calibration tests, the head on the weir was watched closely to insure that steady flow was established and maintained throughout each run, and a record of the water-stage fluctuations was obtained by a continuous recorder.

The rating curves for the Westbury and Syosset weirs are shown in figures 14 and 15 . The measured discharges are shown as dots; the solid line is an average curve defining the discharges in the range of the field measurements. The broken lines represent computed extensions of the rating curve; the computational procedures are discussed in the following paragraphs.

Because in certain large storms tlie instantaneous peak discharges were greater than the maximum measured discharges, the rating curves were extended upward to estimate these maximum discharges. The rating curves were extrapolated by the corbination of two theories-critical flow and uniform flow.

Critical flow is defined as the condition for which the Froude number $(\mathbf{F})$ is equal to unity or, more commonly, at which the specific energy $(E)$ is a minimum for a given discharge (Chow, 1959, p. 42). Critical depth is the depth of a given flow when the specific energy is a minimum.

Critical flow occurs above the crest of the weir in the control section, which is defined as the section where the flow changes from subcritical to supercritical and where the specific energy of the flow is a minimum. As a close approximation, the water depth at the measuring point 3 inches upstream from the weir is assumed to be critical depth. The following relation, developed from the Froude number, describes the flow through the control section :

$$
Q=\sqrt{g \frac{A^{3}}{T}}
$$

where $Q$ is discharge, in cubic feet par second, $A$ and $T$ are the area of flow, in square feet, and water-surface width, in feet, respectively, at the control section, and $g$ is the acceleration due to gravity, in feet per second per second. Since $A$ and $T$ describe the configuration of the cross section as a function of the depth of flow, equation 2 can be solved for the discharge, $Q$, at various depths of flow to develop a stage-discharge relationship. 


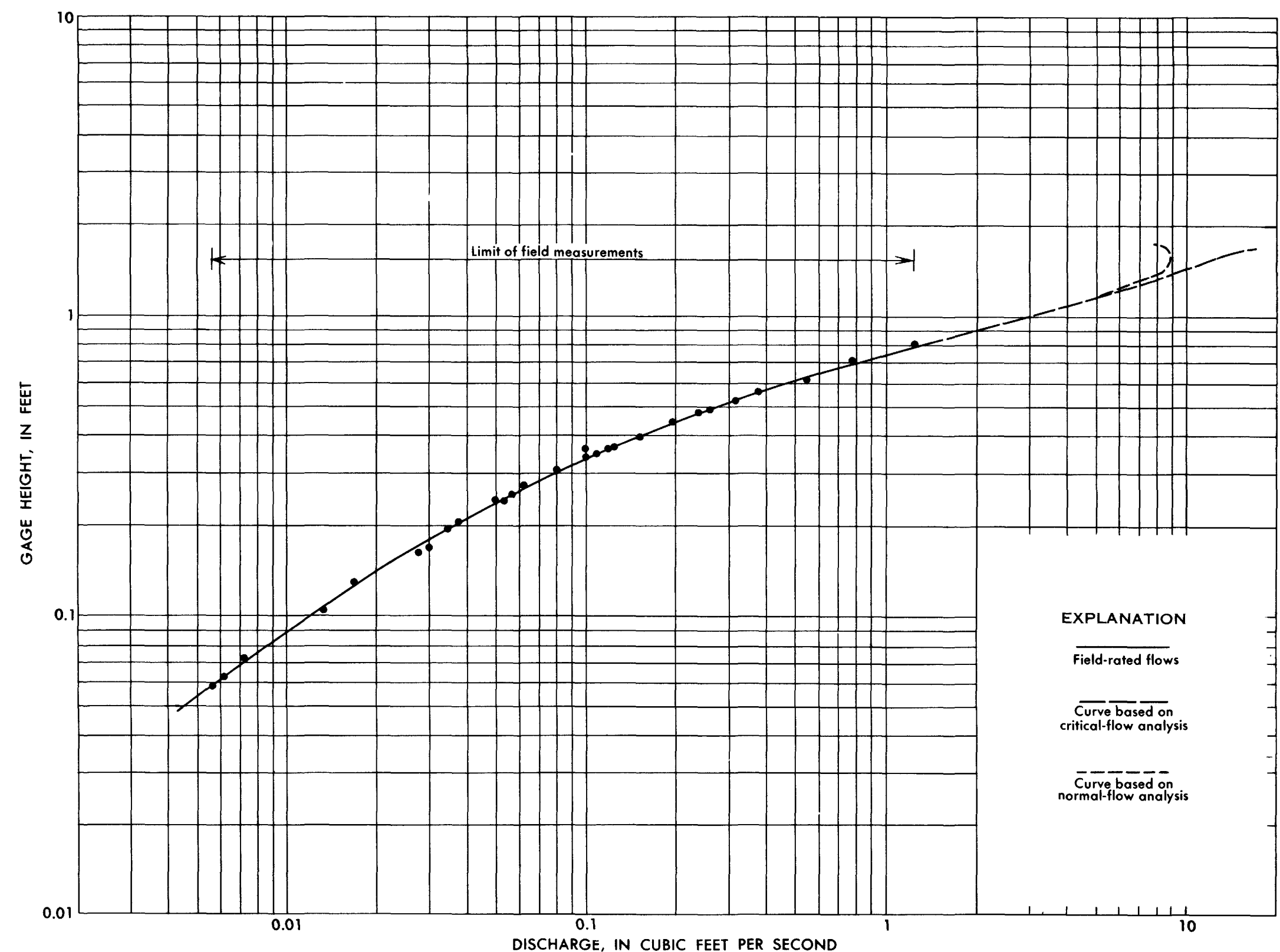

Figure 14.-Rating curve for $V$-notch weir at the Westbury recharge basin. 


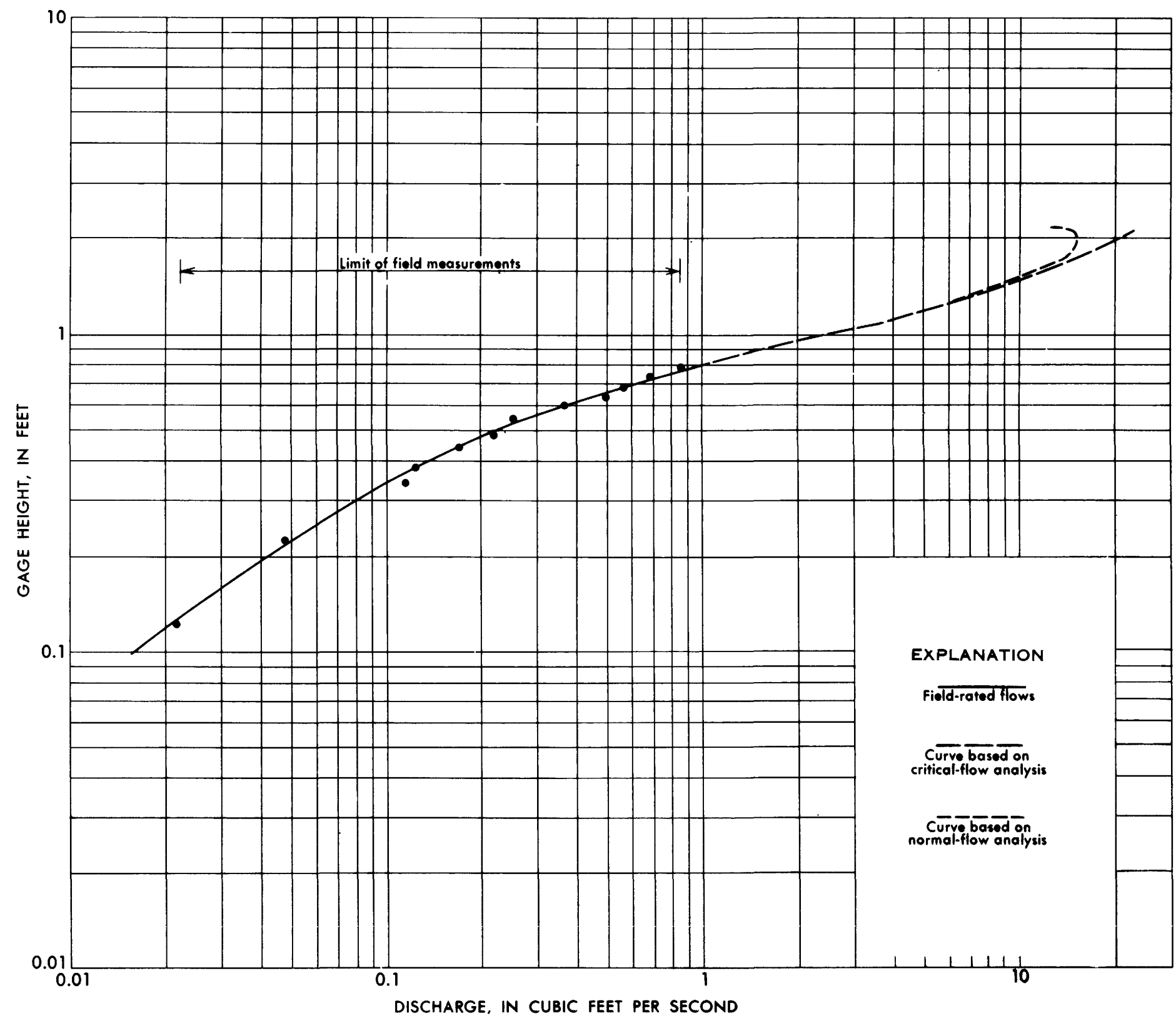


For discharges where the depth of flow is small $(d / D$ less than, or about equal to, 0.5) the streamlines above the measuring point are virtually parallel to the channel bottom, and the hydrostatic law of pressure distribution is applicable-that is, the pressure distribution over the cross section is hydrostatic and is proportional to the depth below the free surface. As the depth of flow increases, the effects of drawdown over the weir extend farther upstream and begin to affect the pressure distribution in the vertical plane above the measuring point. A slight error in the critical-flow relation (eq 2 ) is introduced when the resulting curvilinear streamlines cause a deviation from the hydrostatic pressure distribution over the measuring point. This error increases with increasing depth. Therefore, for large depths of flow, equation 2 does not accurately describe the flow through the control section at the measuring point.

An additional error is introduced at large flow depths. The water-surface width, $T$, decreases as the depth of flow increases in a circular pipe. As a consequence the calculated values of flow using equation 2 become increasingly large, which is contrary to the characteristics of open-channel flow in a circular pipe (Chow, 1959, p. 134-136).

At larger depths of flow, therefore, the flow was estimated by using uniform-flow theory. This theory is based on energy losses due to friction throughout the flow reach. Uniform flow has the characteristics that (1) the depth, water area, velocity, and discharge are constant at every section in the channel and (2) the energy line, water surface, and channel bottom are all parallel (Chow, 1959, p. 89). The depth of flow at uniform flow is called normal depth. The discharge in the smooth concrete inflow pipe was assumed to be uniform and to be described by Manning's equation,

$$
Q=\frac{1.486}{n} A R^{2 / 3} S^{1 / 2},
$$

where $n$ is Manning's coefficient of roughness, $R$ is the hydraulic radius, in feet, and $S$ is the slope of the energy line, water surface, and channel bottom, in feet per foot. $Q$ and $A$ were defined previously.

The discharge was actually calculated by using a modified form of equation 3 that employs a ratio of conveyance $\left(A R^{2 / 3}\right)$, because the roughness and slope of the channel do not change. That is,

$$
Q_{2}=Q_{1} \frac{A_{2}\left(R_{2}\right)^{2 / 3}}{A_{1}\left(R_{1}\right)^{2 / 3}}
$$

Subscript 1 refers to the hydraulic conditions at the highest measured discharge on the field-rated curve, and subscript 2 refers to the hydraulic conditions at any other discharge. In figures 14 and 15 , the theoretical curve based on the critical-flow method merges smoothly with the curve of the rated points, and the two theoretical curves merge with each other very smoothly below about $d / D=0.75$, where $d$ is the depth of flow above the crest of the weir, in feet, and $D$ is the diameter of the pipe, in feet.

At large depths of flow the rating defined by criticaldepth analysis is an upper limit to the actual rating curve, and the rating defined by uniform-flow analysis is probably a lower limit. Therefore, the actual rating curve above $d / D=0.75$ is yet undefined but probably lies between these two limiting curves. In this study, however, only those discharges corresponding to flow depths less than $d / D=0.75$ were used. 